\title{
KERAGAMAN GENETIK POPULASI KAYU KUKU (Pericopsis mooniana, (THWAITES)THWAITES) DI HUTAN LAMEDAI BERDASARKAN PENANDA RAPD
}

Genetic diversity of kayu kuku (Pericopsis mooniana (Thwaites) Thwaites) population at Lamedai forest Southeast Sulawesi based on RAPD markers

ILG. Nurtjahjaningsih ${ }^{1}$, AYPBC Widyatmoko ${ }^{2}$, dan Anto Rimbawanto ${ }^{2}$

${ }^{1}$ Kontributor Utama, ${ }^{1},{ }^{2}$ Balai Bes ar Penelitian dan Pengembangan Bioteknologi dan Pemuliaan Tanaman Hutan Jl. Palag an Tentara Pelajar KM 15, Purwobinangun, Pakem, Sleman, Yogyakarta, Indonesia email: iluh_nc@yahoo.com

Tanggal diterima: 18 Februari 2019, Tanggal direvisi: 20 Februari 2019, Disetujui terbit: 15 Mei 2019

\begin{abstract}
Vulnerable status ofkayu kuku (Pericopsis mooniana) is due to heavilywood harvesting. Aim in this study is to asses genetic diversity and structure ofk ayu kukuat Lamedai forest, Southeast Sulawesi using RAPD markers. Leaves samples were collected from 4 natural populations at Lamedai forest i.e. Lamedai natural reserve, Lamedai village, Balijaya and Tangketada. The 22 polymorphic lociof 5 RAPD markers were subjected to the genetic analysis, binarydata were calculated by GenAlex software to obtain parameters in genetic diversity within population and analysis molecular variant (AMOVA), while PopTree software was used to construct a dendrogram. Results showed that genetic diversity of the 4 populations was in moderatelevel (mean He: 0.361 $\pm 0.017)$ and the values was similar each other. There was no private allele at any populations, indicating that there was no genetic specification. A dendrogram analysis showed that Lamedai natural reserve genetically closed to Tangketada population and Balijaya, while Lamedai was separated into another cluster. AMOVA analysis showed 13\% genetic diversity were observed among populations. In conclution, kayu kuku at Lamedai forest might be a large and continuous population in ancient period.
\end{abstract}

Keywords: natural reserve, genetic diversity, private allele, dendrogram, AMOVA

\begin{abstract}
ABSTRAK
Status konservasi kayu kuku (Pericopsis mooniana) menuju kepunahan di alam liar karena pemanenan kayu yang berlebihan. Penelitian ini bertujuan untuk mengetahui keragaman dan struktur genetik populasi kayu kuku di hutan Lamedai, Sulawesi Tenggara menggunakan penanda RAPD. Sampel daun dikumpulkan dari 4 populasi alam di Cagar Alam Lamedai, des a Lamedai, Balijaya dan Tangketada. Analis is genetik menggunakan 22 lokus polimorfik dari 5 penanda RAPD; data biner dihitung menggunakan piranti lunak GenAlex untuk mengetahui parameter keragaman genetik di dalam populasi dan analisis varians molekuler (AMOVA); sedangkan piranti lunak PopTree digunakan untuk menyusun dendrogram. Hasil penelitian menunjukkan ratarata keragaman genetik dari 4 populasi tersebut pada tingkat sedang (rata-rata He: $0,361 \pm 0,017$ ) dengan nilai yang hampir sama pada semua populasi. Alel privat tidak ditemukan pada 4 populasi tersebut; menunjukkan tidak ada spesifikasi genetik didalampopulasi. Dendrogram mengelompokkan populasi Cagar Alam Lamedai, Tangketada dan Balijaya menjadi satu klaster; sedangkan populasi Lamedai membentuk klaster lain. Berdasarkan analisis AMOVA 13\% keragaman genetik terdapat di antar region/wilayah. Penelitian menyimpulkan bahwa pada jaman dahulu kayu kuku di hutan Lamedai merupakan populasi yang luas atau menyambung.
\end{abstract}

Kata kunci: cagar alam, keragaman genetik, alel privat, dendrogram, AMOVA

\section{PENDAHULUAN}

Kayu kuku (Pericopsis mooniana) bernilai ekonomi tinggi karena kayunya memiliki corak yang sangat bagus. Secara geografis, sebaran alam P. mooniana ditemukan di Sri Langka, Semenanjung Malaysia, Philiphina (Mindanao), New Guinea,
Mikronesia dan Indonesia. Di Indonesia, jenis ini ditemukan di Sumatera bagian Selatan, Kalimantan bagian Timur (Sabah dan Kalimantan Timur), Sulawesi, dan Maluku (Soerianegara \& Lemmens, 1994).

Populasi menyambung merupakan populasi yang didominansi oleh jenis tertentu dengan distribusi yang luas di suatu areal hutan 
(Frantz et al., 2006). Populasi ini dicirikan dengan jumlah individu efektif untuk mendukung terjadinya proses reproduksi sehingga aliran gene (gene flow) terjaga dengan baik. Hutan Lamedai di Kolaka, Sulawesi Tenggara merupakan salah satu habitat kayu kuku. Pada awalnya populasi kayu kuku di hutan Lamedai merupakan populasi yang menyambung (Ardiansyah, komunikasi pribadi). Namun kondisi saat ini populasi kayu kuku telah terfragmentasi membentuk sub-sub populasi disebabkan konversi lahan menjadi kebun kelapa sawit, pemukiman penduduk dan bandara (Ardiansyah, komunikasi pribadi). Dalam jangka waktu lama, populasi yang terfragmentsi dapat mengalami perubahan susunan genetik antar sub populasi (Frantz et al., 2006; Kruse et al., 2018; Torokeldiev, Ziehe, Gailing, \& Finkeldey, 2019). Perbedaan karakter genetik ini disebabkan oleh pola gene flow. Kelompok jenis konifer yang sebaran serbuk sari maupun biji dibantu oleh angin, memiliki gene flow yang luas hingga puluhan kilometer (Eliades, Fady, Gailing, Leinemann, \& Finkeldey, 2018); sebaliknya kelompok jenis daun lebar yang sebarannya dibantu oleh serangga, burung dan gravitasi umumnya memiliki sebaran yang tidak terlalu luas, hanya puluhan meter (Frantz et al., 2006). Oleh karena masing-masing sub-populasi memiliki karakter keragaman genetik yang berbeda-beda maka identifikasi sub-populasi menggunakan penanda DNA perlu dilakukan, selanjutnya digunakan untuk menyusun strategi pengayaan materi genetik, pemindahan benih atau bibit dari populasi asal maupun pembangunan plot konservasi (Maldia et al., 2017).

Penanda RAPD (Random Amplified Polymorphism DNA) merupakan salah satu penanda DNA yang bersifat dominan, memiliki panjang 10 pasangan basa (bp) dan menempel secara acak pada untai DNA. Penanda ini mudah dan efektif dalam mendeteksi keragaman genetik karena memiliki polymorphism yang tinggi.
Penanda RAPD digunakan untuk mengidentifikasi keragamaan genetik populasi pohon induk (Nurtjahjaningsih, Sulistyaw ati, \& Rimbawanto, 2015), anakan (Nurtjahjaningsih, Sukartiningsih, Saranti, Sulistyawati, \& Rimbawanto, 2017), klon (Nurtahjaningsih, Heraw an, Rachma, \& Rimbawanto, 2018) dan menduga sistem perkawinan pada tanaman kehutanan (Nurtjahjaningsih, et al., 2017).

Tujuan penelitian ini adalah untuk mengetahui keragaman dan struktur genetik kayu kayu di hutan Lamedai menggunakan penanda RAPD. Informasi genetik ini dapat digunakan dalam menyusun strategi konservasi genetik dan restorasi kayu kuku.

\section{BAHAN DAN METODE}

\section{A. Wak tu dan lokasi penelitian}

Penelitian ini dilakukan selama 3 bulan mulai bulan Juni sampai dengan September 2017. Sampel daun untuk template DNA berasal dari empat populasi di hutan Lamedai Kabupaten Kolaka Provinsi Sulawesi Tenggara yaitu populasi desa Lamedai, Balijaya, Tangketada dan Cagar Alam Lamedai. Lokasi pengambilan sampel disajikan pada Gambar 1 . Penanganan sampel, isolasi dan analisis DNA dilakukan di laboratorium Genetika Molekuler Balai Besar Litbang Bioteknologi dan Pemuliaan Tanaman Hutan, Yogyakarta

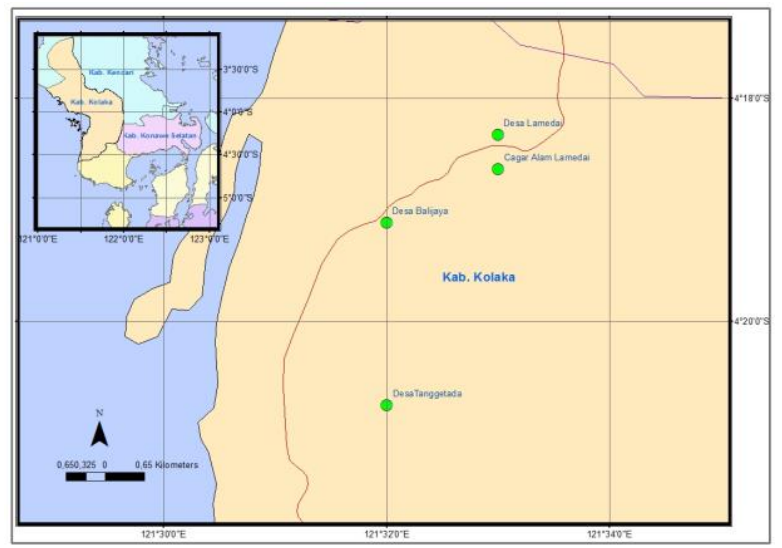

Gambar 1. Lokasi pengambilan sampel daun kayu kuku dihutan Lamedai (Sumber : GPS by ILG, GIS modifikasi by Diro 2017) 


\section{B. Bahan dan alat penelitian}

1. Bahan

Bahan yang digunakan pada penelitian ini berupa sampel daun kayu kuku, bahan kimia seperti 1x buffer CTAB, chloroform, isopropanol dan ethanol 70\% dan 100\%; PCR kit (KAPATaq Extra HotStart-KAPA Biosystem), penanda RAPD (Operon), gel agarose 1,2 \% (Invitrogen), 1x buffer EDTA dan Ethidium bromide.

\section{Alat}

Alat yang digunakan pada penelitian ini antara lain timbangan analitik (Metller Teledo), mesin penghancur daun (Biospec Products), centrifuge (Eppendoft), pipet (Gilson), nanoview (GE Healthcare), mesin PCR (Perkin Elmer), microwave, mesin elektroforesis (OWL) dan piranti lunak GelDoc (Biorad).

\section{Metode penelitian}

Sampel daun yang sudah dikumpulkan di lokasi penelitian dimasukkan dalam amplop dan disimpan dalam wadah (plastik klip) yang sudah diisi silika gel seperti yang dilakukan oleh Nurtjahjaningsih, Sukartiningsih, Saranti, et al., (2017). Jumlah sampel daun per populasi disajikan pada Tabel 2. Sampel daun dari populasi Balijaya, Tangketada, Cagar Alam Lamedai dan desa Lamedai masing-masing berjumlah 37, 24, 35 dan 24 sampel; menggunakan 5 penanda RAPD; sehingga total sampel yang digunakan sebanyak 600 sampel.

Proses ekstraksi DNA melalui 3 tahapan yaitu proses lisis (pemecahan dinding sel), isolasi DNA dan memurnikan DNA. Untuk mempermudah pemecahan dinding sel, sampel daun seberat $\pm 50 \mathrm{mg}$ ditimbang menggunakan timbangan analitik (Metller Teledo) dan dihaluskan menggunakan mesin penghalus daun, minibeadbeater-8 (Biospec Products). Proses lisis menggunakan metode CTAB (Shiraishi \& Watanabe, 1995). Isolasi DNA menggunakan EDTA. Proses pemurnian pelet DNA menggunakan ethanol pada konsentrasi berturut-turut $70 \%$ dan $100 \%$ (Merck).
Kemudian konsentrasi DNA diukur dalam satuan ng/L dan kemurnian DNA diukur pada absorbansi 260/280 nm menggunakan alat nanovue (GE Healthcare).

Proses PCR adalah proses perbanyakan fragmen DNA target. Penanda RAPD yang digunakan pada penelitian ini diperoleh dengan cara memilih/ screening 60 primer RAPD (data tidak dipublikasikan). Lima dari 60 primer RAPD, yaitu OPA12, OPD03, OPO11, OPW04 dan OPZ05 (Operon) bersifat stabil dan polimorfik dan digunakan untuk analisis genetik. Nama dan sekuen 5 penanda RAPD yang digunakan disajikan pada Tabel 1. Larutan PCR dan kondisi mesin thermal cycler 9700 (Perkin Elmer) berdasarkan protokol KAPATaq polymerase (KAPATaq Extra HotStart-KAPA Biosystem) dan sudah diuraikan pada penelitian sebelumnya (Nurtjahjaningsih, Sukartiningsih, Saranti, et al., 2017). Untuk mengidentifikasi fragmen DNA hasil PCR dilakukan elektroforesis (OWL). Visualisasi hasil elektroforesis menggunakan piranti lunak GelDoc (Biorad).

\section{Analisis data}

Pengumpulan data genetik berdasarkan alel polimorfik dengan menggunakan data scoring (data biner) yaitu skor 1 (satu) apabila ada pita fragment, sedangkan skor 0 (nol) tidak ada pita.

Parameter keragaman genetik di dalam populasi menggunakan alel privat dan nilai heterozigositas harapan ( $\mathrm{He})$. Analisis klaster atau dendogram menggambarkan hubungan kekerabatan secara genetik antar populasi. Jarak genetik dihitung berdasarkan frekuensi alel per lokus per populasi. Pohon phylogenetik disusun berdasarkan UPGMA (unweighted pair-group methid with arithmetic mean) dengan uji bootstrap sebesar 999 ulangan. AMOVA (analysis molecular variant) menunjukkan pengaruh wilayah (region), populasi dan individu terhadap keragaman genetik. Berdasarkan kedekatan geografis, empat populasi dikelompokkan menjadi 3 wilayah 
yaitu Cagar Alam Lamedai dan Tangketada (wilayah 1), desa Balijaya (wilayah 2) dan Lamedai (wilayah 3). Penghitungan parameter keragaman genetik di dalam populasi dan AMOVA menggunakan piranti lunak GenAlex versi. 6.41. (Peakall \& Smouse, 2006), sedangkan analisis klaster menggunakan piranti lunak POPTREEW (Takesaki, Nei, \& Tamura, 2014).

\section{HASIL DAN PEMBAHASAN}

\section{A. Hasil}

Karakteristik lima penanda RAPD meliputi sekuen primer, jumlah dan ukuran lokus ditunjukkan pada Tabel 1. Jumlah lokus yang bersifat polimorfik berkisar antara 1 (OPW04) sampai 9 (OPZ05). Ukuran lokus polimorfik berkisar 500 sampai 1.300 base pairs (bp). Meskipun OPW04 mempunyai jumlah alel yang paling sedikit, primer ini memiliki frekuensi alel polimorfik yang paling tinggi $(0,760)$ jika dibandingkan dengan primer lainnya. Jumlah total alel polimorfik yang digunakan adalah 22 alel.

Berdasarkan 22 lokus polimorfik, keragaman genetik populasi kayu kuku disajikan pada Tabel 2. Jumlah sampel yang digunakan antara 24 sampai 37. Alel privat tidak ditemukan pada populasi manapun. Nilai keragaman genetik $(\mathrm{He} \pm \mathrm{SE})$ hampir sama pada semua populasi dengan nilai rata-rata 0,361 . Nilai He berturut dari rendah ke tinggi yaitu 0,349 (Balijaya), 0,355 (Lamedai), 0,357 (Tangketada) dan 0,383 (Cagar Alam).

Tabel 1. Karakteristik lima primer RAPD, sekuen primer, jumlah, kisaran frekuensi dan ukuran lokus polimorfik

\begin{tabular}{|c|c|c|c|c|}
\hline $\begin{array}{l}\text { Nama primer } \\
\text { RAPD }\end{array}$ & Sekuen 5'-3' (bp) & $\begin{array}{c}\text { Jumlah lokus } \\
\text { polimorfik }\end{array}$ & $\begin{array}{l}\text { Ukuran lokus } \\
\text { polimorfik (bp) }\end{array}$ & $\begin{array}{c}\text { Kisaran frekuensi } \\
\text { alel }\end{array}$ \\
\hline OPA12 & TCGGCGATAG & 3 & $550,600,650$ & $0,125-0,625$ \\
\hline OPD03 & GTCGCCGTCA & 4 & $\begin{array}{r}600,800,1000 \\
1100\end{array}$ & $0,208-0,635$ \\
\hline OPO11 & GACAGGAGGT & 5 & $\begin{array}{r}600,680,900 \\
1000,1100\end{array}$ & $0,354-0,813$ \\
\hline OPW04 & CAGAAGCGGA & 1 & 700 & 0,760 \\
\hline OPZ05 & ACTCGTAGCC & 9 & $\begin{array}{r}500,600,650,700 \\
750,800,900 \\
1050,1300\end{array}$ & $0,125-0,688$ \\
\hline & Total & 22 & & \\
\hline
\end{tabular}

Tabel 2. Parameter keragaman genetik populasi kayu kuku

\begin{tabular}{llccc}
\hline Populasi & Kondisitegakan & N & Alel privat & He \pm SE \\
\hline Balijaya & Pemukiman penduduk & 37 & 0 & $0,349 \pm 0,030$ \\
Tangketada & Lahan persiapan Bandara & 24 & 0 & $0,357 \pm 0.036$ \\
Cagar Alam Lamedai & Cagar Alam & 35 & 0 & $0,383 \pm 0.031$ \\
Lamedai & Bekas tebangan & 24 & 0 & $0,355 \pm 0,042$ \\
\hline Jumlah/Rata-rata & & 120 & 0 & $0,361 \pm 0,017$ \\
\hline
\end{tabular}

Keterangan: N: Jumlah sampel, He: heterozygositas harapan, SE: standard error

Analisis dendrogram mengelompokkan populasi berdasarkan kedekatan genetik. Populasi kayu kuku di Cagar Alam Lamedai, Tangketada dan Balijaya membentuk satu klaster; sedangkan populasi Lamedai terpisah dari 3 populasi yang lain (Gambar 2).
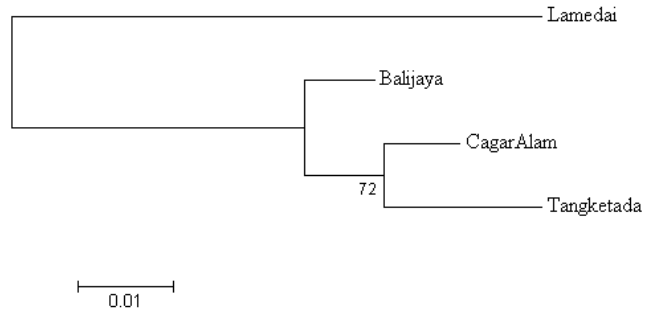

Gambar 2. Dendrogramantar populasi kayu kuku 
Didalam sub klaster, Cagar Alam Lamedai terpisah dari Tangketada dengan tingkat kepercayaan $72 \%$. Tingkat kepercayaan diatas $50 \%$ ini menunjukkan bahwa populasi tersebut terpisah secara genetik.

Analisis AMOVA memperjelas hasil analisis dendrogram. Analisis AMOVA menunjukkan bahwa nilai sebesar 13\% keragaman genetik terjadi antar wilayah (region); 5\% terjadi antar populasi dan $82 \%$ terjadi antar individu (Tabel 3). Nilai variasi tersebut tergolong besar dan nilainya signifikan.

Tabel 3. AMOVA menunjukkan susunan 120 individu kayu kuku dikelompokkan dalam 3 wilayah dan 4 populasi

\begin{tabular}{lcrrr}
\hline Sumber keragaman & $\mathrm{db}$ & \multicolumn{1}{c}{ SS } & MS & Variasi $(\%)$ \\
\hline Antar wilayah & 2 & 70,136 & 35,068 & $13 * * *$ \\
Antarpopulasi & 1 & 10,659 & 10,659 & $5 * *$ \\
Antarindividu & 116 & 478,297 & 4,123 & $82 * * *$ \\
Total & 119 & 559,092 & & 100 \\
\hline
\end{tabular}

Keterangan: db: derajat bebas; SS: jumlah kuadrat; MS: rerata kudrat; ** $p$-value - 0,01

\section{B. Pembahasan}

Jumlah penanda RAPD yang biasa digunakan pada studi keragaman genetik bervariasi dari 5 penanda RAPD dengan 40-80 alel polimorfik (Liber et al., 2014; Nurtjahjaningsih, Sukartiningsih, Saranti, et al., 2017; Rosmaina \& Zulfahmi, 2013) hingga 20 penanda RAPD dengan 100 alel polimorfik (Mendonca et al., 2014). Apabila dibandingkan dengan penelitian lainnya, penanda RAPD yang digunakan pada penelitian ini tidak terlalu banyak yaitu 5 penanda RAPD dengan 22 alel polimorfik, rata-rata 4 alel polimorfik per primer. Hal ini disebabkan perhitungan data skoring dilakukan pada lokus yang bersifat stabil saja untuk mengantisipasi karakter penanda RAPD yang tidak stabil. Meskipun jumlah alel yang digunakan tidak terlalu banyak, namun tingkat polimorfisme mencapai $100 \%$, sehingga penanda ini cukup kuat untuk membedakan populasi.

Nilai keragaman genetik dari 4 populasi kayu kuku di hutan Lamedai termasuk dalam nilai sedang (HE rata-rata: 0,361) apabila dibandingkan dengan Genus Pericopsis lainnya seperti $P$. elata berkisar antara 0,353-0,841 (Micheneau, Dauby, Bourland, Doucet, \& Hardy, 2011). Suatu jenis mampu mempertahankan keragaman genetik salah satunya disebabkan oleh rentang aliran gen (gene flow) yang luas dan nilai perkawinan silang (outcrossing) yang tinggi. Pada jenis daun jarum (konifer), sebaran serbuk sari dibantu oleh angin, sehingga jarak sebarannya bisa mencapai puluhan kilometer. Demikian pula dengan jenis yang memiliki biji bersayap dan berukuran kecil, sebaran bijinya dapat lebih jauh, seperti pada jenis Pinus dan Picea (Kitamura, Nakanishi, Lian, \& Goto, 2018). Berbeda dengan jenis konifer, kayu kuku yang termasuk jenis polong-polongan, memiliki serbuk sari yang bersifat lengket dan sebarannya dibantu oleh hewan seperti serangga (Fidalgo, Guimaraes, Caldiron, \& Barbosa, 2018). Pada umumnya serbuk sari yang disebarkan oleh serangga, jarak sebarannya tidak terlalu jauh, hanya puluhan meter saja (Beseega, Pometti, Campos, Saidman, \& Vilardi, 2017). Selain itu, apabila buah kayu kuku masak maka buah akan membuka dengan biji masih menempel pada kulit buah yang bergabus dan berat sehingga bijinya disebarkan oleh gravitasi. Jenis dengan sebaran biji oleh gravitasi seperti pada buah ulin, umumnya memiliki kekerabatan genetik tinggi antar individu pohon (Nurtjahjaningsih, Sukartiningsih, Kurokochi, Saito, \& Ide, 2017). Dua karakter mekanisme gene flow yang dimiliki tersebut di atas, menyebabkan keragaman genetik pada kayu kuku tidak terlalu tinggi. Namun demikian, oleh karena karakter biologi kayu kuku yang berbunga sepanjang 
tahun, maka jenis ini dapat menjamin ketersediaan bunga dan benih sepanjang tahun (Yuniarti \& Syamsuwida, 2011). Jenis dengan karakter pembungaan sepanjang tahun mampu mempertahankan keragaman genetik (Nurtjahjaningsih, Saito, Tsuda, \& Ide, 2007).

Populasi Cagar Alam Lamedai memiliki keragaman genetik tertinggi, dan nilai terendah di populasi desa Lamedai. Perbedaan karakter keragaman genetik ini disebabkan jumlah pohon induk berlimpah dan areal hutan yang menyambung (continuous) di Cagar Alam, sebaliknya jumlah pohon induk dan areal terfragmentasi di desa Lamedai. Pada kondisi ideal seperti pembungaan serentak dan habitat yang menyambung, populasi dengan keragaman genetik tinggi lebih mampu mempertahankan keragamannya (Nurtjahjaningsih et al., 2007). Sebaliknya, habitat yang terfragmentasi merupakan ancaman bagi keragaman genetik karena menghilangkan variasi alel (gene pool) dan secara nyata meningkatkan nilai inbreeding (Bittencourt \& Sebben, 2009). Jumlah pohon dan proses keberhasilan reproduksi yang terbatas menjadi kendala untuk melestarikan populasi yang terfragmentasi (Browne, Ottewell, Sork, \& Karubian, 2018; Vieria, Fajardo, Souza, \& Carvalho, 2010).

Keragaman genetik 4 populasi yang digunakan pada penelitian ini menunjukkan nilai yang hampir sama pada semua populasi. Alel spesifik yang mencirikan keunikan populasi juga tidak ditemukan di semua populasi. Hal ini mengindikasikan kayu kuku di hutan Lamedai dan sekitarnya pada awalnya merupakan populasi yang menyambung. Indikasi ini diperkuat dengan hasil analisis dendrogram dan AMOVA pada penelitian ini. Dendrogram mengelompokkan populasi yang secara geografis terpisah namun secara genetik membentuk satu klaster. Analisis AMOVA juga menunjukkan bahwa hanya $13 \%$ dari nilai keragaman genetik terjadi karena perbedaan wilayah. Populasi menyambung dicirikan dengan nilai keragaman yang hampir sama, serta nilai kawin kerabat tidak signifikan, tidak membentuk struktur genetik, dan berkerabat secara genetik meskipun terbagi menjadi sub populasi, seperti pada Acacia mangium di Queensland (Butcher, Harwood, \& Quang, 2004; Gomez, Lillo, \& Gonzalez, 2012). Karakterisasi genetik pada suatu populasi akan menentukan penyusunan strategi konservasi suatu jenis (Tsuda \& Ide, 2005) maupun restorasi ke habitat aslinya (VillalobosBarrantes, Garcia, Lowe, \& Albertazzi, 2015).

Untuk mendukung informasi indikasi populasi menyambung kayu kuku di hutan Lamedai, dapat dilihat dari karakter biologis jenis tersebut sebagai berikut: Seperti famili Leguminosae lainnya, kayu kuku mempunyai serbuk sari yang basah/lengket, sehingga diyakini penyerbukannya dibantu oleh serangga (Gomez et al., 2012). Serangga merupakan agen penyerbuk yang cukup efektif sehingga menyebarkan serbuk sari dengan jarak yang luas dalam suatu hamparan hutan yang menyambung (Nurtjahjaningsih et al., 2012). Selain disebabkan karena pengaruh gravitasi, biji pada kayu kuku dapat disebarkan oleh hewan pemakan buah (frugivora) sebangsa burung, sehingga jarak sebarannya menjadi lebih luas (Beseega et al., 2017; Dlamini, Zachariades, \& Downs, 2018), dan cukup efektif menyambungkan sub-sub populasi menjadi populasi yang luas (Mueller, Lenz, Caprano, Fiedler, \& Gaese, 2014).

\section{KESIMPULAN}

Keragaman genetik kayu kuku dari empat populasi di hutan Lamedai, Sulawesi Tenggara tergolong sedang. Populasi kayu kuku di Cagar Alam Lamedai dengan populasi di sekitarnya yaitu desa Lamedai, Balijaya dan Tangketada mengindikasikan populasi yang menyambung. Oleh karena tidak ada kespesifikan genetik pada masing-masing populasi, maka perbedaan populasi bukan menjadi pertimbangan untuk memisahkan populasi tersebut. Untuk membangun plot konservasi, direkomendasikan untuk memprioritaskan populasi Cagar Alam 
Lamedai karena mempunyai keragaman genetik yang paling tinggi dibandingkan 3 populasi lainnya. Namun demikian, oleh karena keragaman genetik di luar wilayah Cagar Alam juga mempunyai nilai keragaman genetik yang hampir sama, maka agar tidak mengganggu tegakan CA, maka disarankan untuk mengoleksi materi genetik di luar CA.

\section{UCAPAN TERIMA KASIH}

Penelitian ini dibiayai oleh anggaran DIPA KLHK. Penulis menyampaikan terimakasih kepada Sdri. Wahyunisari yang membantu analisis DNA di Laboratorium Genetika Molekuler BBPPBPTH. ILG berkontribusi dalam analisis data dan penyusunan naskah, sedangkan AYPBC dan AR berkontribusi dalam mereview naskah.

\section{DAFTAR PUSTAKA}

Beseega, C., Pometti, C., Campos, C., Saidman, B., \& Vilardi, J. (2017). Implications of mating system and pollen dispersal indicates for management and conservation of the semi-arid species Prosopis flexuosa (Leguminosae). Forest Ecology and Management, 400, 218227.

https://doi.org/10.1016/j.foreco.2017.06.007

Bittencourt, J. V. M., \& Sebben, A. M. (2009). Genetic effects of forest fragmentation in highdensity Araucaria angustifolia populations in Southern Brazil. Tree Genetics \& Genomes, 5(4), 573-582.

Browne, L., Ottewell, K., Sork, V. L., \& Karubian, J. (2018). The relative contributions of seed and pollen dispersal to gene flow and genetic diversity in seedlings of a tropical palm. Molecular Ecology, 27, 3159-3173.

Butcher, P., Harwood, C., \& Quang, T. H. (2004). Studies of mating systems in seed stands suggest possible causes of variable outcrossing rates in natural populations of Acacia mangium. Forest Genetics, 11(3-4), 303-309.

Dlamini, P., Zachariades, C., \& Downs, C. T. (2018). The effect of frugivorous birds on seed dispersal and germination of the invasive Brazilian peppertree (Schinus terebinthifolius) and Indian laurel (Litsea glutinosa). South African Journal of Botany, 114, 61-68.

Eliades, N.-G. H., Fady, B., Gailing, O., Leinemann, L., \& Finkeldey, R. (2018). Significant pattems
ILG Nurtjahjaningsih, AYPBC Widyatmoko dan Anto Rimbawanto

of fine-scale spatial genetic structure in a narrow endemic wind-dispersed tree species, Cedrus brevifolia Henry. Tree Genetics \& Genomes, 14:15.

Fidalgo, A. de O., Guimaraes, D. M., Caldiron, G. T., \& Barbosa, J. M. (2018). Reproductive ecology of two pioneer legumes in a coastal plain degraded by sand mining. Hoehnea, 45(1).

https://doi.org/10.3389/fgebe.2018.00490

Frantz, A. C., Poutois, J. T., Heuertz, M., Schley, L., Flamand, M. C., Krier, A., ... T. Burke. (2006). Genetic structure and as sigment tests demonstrate illegal translocation of red deer (Cervus elaphus) into a continuous population. Molecular Ecology, 15, 3191-3203.

Gomez, P., Lillo, D., \& Gonzalez, A. . (2012). Pollination and breeding system in Adesmia bijuga Phil.(Fabaceae), a critically endangered species in Central Chili. Gayana Botany, 69(2), 286-295.

Kitamura, K., Nakanishi, A., Lian, C., \& Goto, S. (2018). Distinctions in fine-scale spatial genetic structure between growth stages of Picea jezoensis Carr. Frontiers in Genetics.

Kruse, S., Epp., L. S., Wieczorek, M., Pestryakova, L. A., Stoof-Leichsenring, K. R., \& Herzschuh, U. (2018). High gene flow and complex treeline dynamics of Larix Mill. stands on the Taymyr Peninsula (north-central Siberia) revealed by nuclear microsatellites. Tree Genetics \& Genomes, 14(2), 14-19. https://doi.org/https://doi.org/10.1007/s 11295018-1235-3

Liber, Z., Zidovec, V., Bogdanovic, S., Radosavljevic, I., Prusa, M., Filipovic, M., ... Satovic, Z. (2014). Genetic diversity of dalmatian sage (Salvia officinalis L.) as assessed by RAPD markers. Agriculturae Conspectus Scientificus, 79(2), 77-84.

Maldia, L. S. J., Matsumoto, A., Ueno, S., Kanazashi, A., Kanno, M., \& Namikawa, K. (2017). Geographic patterns of genetic variation in nuclear and chloroplast genomes of two related oaks (Quercus aliena and $Q$. serrata) in Japan: implications for seed and seedling transfer. Tree Genetics \& Genomes, 13(121).

Mendonca, E. G., Souza, A. M. d., Vieira, F. d. A., Estopa, R. A., Reis, C. A. F., \& Carvalho, D. d. (2014). Using Random Amplified Polymorphic DNA to Assess Genetic Diversity and Structure of Natural Calophyllum brasiliense (Clusiaceae) Populations in Riparian Forests. Hindawi Internatioan Journal of Forest Research. 
Micheneau, C., Dauby, G., Bourland, N., Doucet, J.L., \& Olivier J. Hardy. (2011). Development and characterization of microsatellite loci in Pericopsis elata (Fabaceae) using a costefficient approach. American Journal of Botany, e268-e270.

Mueller, T., Lenz, J., Caprano, T., Fiedler, W., \& Gaese, K. B. (2014). Large frugivorous birds facilitate functiaonal connectivity of fragmented landscapes. Journal of Appiled Ecology, 51, 684-692

Nurtahjaningsih, I. L. G., Herawan, T., Rachma, R. P., \& Rimbawanto, A. (2018). Pengujian penanda Random Amplified Polymorphism DNA untuk mengetahui kestabilan genetik klon jati (Tectona grandis). Jurnal Pemuliaan Tanaman Hutan, 12(2), 105-135.

Nurtjahjaningsih, I. L. G., Saito, Y., Tsuda, Y., \& Ide, Y. (2007). Genetic diversity of parental and offs pring populations in a Pinus merkusii seedling seed orchard detected by microsatellite markres. Bulletin-Tokyo University Forest, 118, 1-14.

Nurtjahjaningsih, I. L. G., Sukartiningsih, Kurokochi, H., Saito, Y., \& Ide, Y. (2017). Genetic structure of the tropical tree Eusideroxylon zwageri in Indonesia revealed by chloroplast DNA phylogeography. Forests, 8(7). https://doi.org/10.3390/f8070229

Nurtjahjaningsih, I. L. G., Sukartiningsih, Saranti, A., Sulistyawati, P., \& Rimbawanto, A. (2017). Kekerabatan genetik anakan alam ulin (Eusideroxylon zwageri TEIJSM. \& BINN.) menggunakan penanda Random Amplified Polymorphism DNA. Jurnal Pemuliaan Tanaman Hutan, 11(1), 25-31.

Nurtjahjaningsih, I. L. G., Sulistyawati, P., \& Rimbawanto, A. (2015). Struktur genetik Calliandra calothyrsus di Indonesia menggunakan penanda Random Amplified Polymorphism DNA (RAPD). Jurnal Pemuliaan Tanaman Hutan, 10(1), 31-38.

Nurtjahjaningsih, I. L. G., Sulistyawati, P., Widyatmoko, A., \& Rimbawanto, A. (2012). Karakteristik pembungaan dan sistem perkawinan nyamplung (Calophyllum inophyllum) padahutan tanaman di Watusipat, Gunung Kidul. Jurnal Pemuliaan Tanaman Hutan, 6(2), 65-80.

Peakall, R., \& Smouse, P. E. (2006). GenAlex 6: Genetic analysis in excel, Population genetic software for teachng and research. Molecular Ecology Notes, 6, 288-295.
Rosmaina, \& Zulfahmi. (2013). Genetic diversity of Eurycoma longifolia Jack based on random amplified polymorphic DNA marker. JMHT, 19(2), 138-144.

Shiraishi, S., \& Watanabe, A. (1995). Identification of chloroplast genome between Pinus densiflora Sieb et Zucc and P. thumbergii Parl based on the polymorphism in rbcL gene. Journal of Japanese Forestry Society, 77, 429436.

Soerianegara, I., \& Lemmens, R. H. M. J. (1994). Plant Resources of South-East Asia 5: (1) Timber trees: Major commercial timbers. (I. Soerianegara \& R. H. M. J. Lemmens, Eds.). Bogor Indonesia: Prosea Foundation.

Takesaki, N., Nei, M., \& Tamura, K. (2014). POPTREEW: Web version of POPTREE for Constructing Population Trees from Allele Frequency Data and Computing Some Other Quantities. Molecular Biology Evolution, 31(6), 1622-1624.

Torokeldiev, N., Ziehe, M., Gailing, O., \& Finkeldey, R. (2019). Genetic diversity and structure of natural Juglans regia L. populations in the southern Kyrgyz Republic revealed by nuclear SSR and EST-SSR markers. Tree Genetics \& Genomes, 15(5). https://doi.org/https://doi.org/10.1007/s 11295018-1311-8

Tsuda, Y., \& Ide, Y. (2005). Wide-range analys is of genetic structure of Betula maximowicziana, a long-lived pioneer tree species and noble hardwood in the cool temperate zone of Japan. Molecular Ecology, 14(13).

Vieria, F. de A. V., Fajardo, C. G., Souza, A. M. de, \& Carvalho, D. de. (2010). Landscape-level and fine-scale genetic structure of the Neotropical tree Protium spruceanum (Burseraceae). International Journal of Forestry Research. https://doi.org/doi:10.1155/2010/120979

Villalobos-Barrantes, H. M., Garcia, E., Lowe, A. J., \& Albertazzi, F. (2015). Genetic analys is of the dry forest timber tree Sideroxylon capiri in Costa Rica using AFLP. Plant Systematics and Evolution, 301(11). https://doi.org/DOI 10.1007/s 00606-014-1049-1

Yuniarti, N., \& Syamsuwida, D. (2011). Kayu Kuku (Pericopsis mooniana THW). In Atlas Benih Tanaman Hutan Indonesia Jilid II (pp. 32-34). Bogor: Balai Penelitian Teknologi Perbenihan Tanaman Hutan. 